\title{
EFEKTIVITAS PEMBELAJARAN DITINJAU DARI PELAKSANAAN SUPERVISI
}

\author{
Fitriadi Lubis \\ Dosen IAIN Padangsidimpuan \\ Korespondensi: JL. H. T. Rizal Nurdin KM. 4,5 Sihitang, Kecamatan Padangsidimpuan Tenggara, \\ Sihitang, Padangsidimpuan, Kota Padang Sidempuan, Sumatera Utara 22733. \\ e-mail: fitriadilubis@yahoo.co.id
}

\begin{abstract}
The purpose of this research is to examine the relationship between teachers' perception about supervision and teaching effectiveness. The data was obtained from 40 teachers. The instrument used in this research was questionnaire. The data was analyzed by using SPSS proram. The result of this study shown that the correlation between teachers' perception about supervision and teaching effectiveness was 0.43. the contribution of teachers' perception variable was $0.18 \%$ to teaching effectiveness variable.
\end{abstract}

Keywords: supervision, teaching effectiveness.

\section{PENDAHULUAN}

$\mathrm{G}$ uru adalah pelaksana operasional di sekolah. Mereka mengemban tugas inti sekolah, sedangkan pelaksana lain diharapkan dapat berperan sebagai penunjang kelancaran tugas guru tersebut. Oleh sebab itu, usaha organisasi sekolah sebaiknya lebih banyak dipusatkan kepada pembinaan guru. Sebab factor yang menentukan dalam mencapai tujuan pendidikan adalah guru yang baik. Guru yang baik adalah guru yang berkepribadian tinggi. Guru yang berkepribadian tinggi dimaksud adalah guru yang memandang pendidikan sebagai alat untuk meningkatkan kesejahteraan manusia, dan mereka itu adalah orang yang mengabdi secara antusias terhadap pekerjaan mengajar.

Tugas dan tanggung jawab para guru sangat berat. Mereka ini berusaha demi tercapainya tujuan-tujuan pengajaran yang telah ditetapkan. Tugas guru tidak hanya sekedar menyampaikan materi pelajaran saja, akan tetapi ia harus membina, mengembangkan sikap dan mental para siswa.

Peningkatan kualitas guru diusahakan secara terus menerus. Usaha itu misalnya meningkatkan kemampuan dan penegtahuan para guru melalui peningkatan mutu pendidikan formal calon guru, dan penataran-penataran. Namun hingga saat ini masih terlihat tanda-tanda bahwa realisasinya belum memuaskan.

Guru sebagai pelaksana proses belajar mengajar memerlukan berbagai kemampuan yang memadai, kemampuan itu meliputi kemampuan membuat rencana pengajaran, menyajikan serta mengevaluasinya. Kemampuan guru tersebut belum sepenuhnya menjamin keefektifan pengajaran. Faktor lain yang mungkin berpengaruh ialah pelaksanaan supervisi kepala sekolah. Bagaimana persepsi guru terhadap supervisi kepala sekolah apakah sebagai pengawas atau sebagai alat bantuan perbaikan pengajaran. Semuanya itu tergantung kepada 
bagaimana guru melihat mendengar dan mengalami ketika guru melakukan supervisi.

Perbedaan persepsi mengenai supervisi, baik para kepala sekolah maupun pada pengawas akan mempunyai dampak terhadap efektivitas pengajaran. Guru dan pengawas mungkin berbeda persepsinya terhadap supervisi. Supervisi mungkin dianggap sebagai alat kontrol yakni sebagai alat untuk mencari-cari kesalahan guru semata, atau mungkin juga sebagai bantuan juga. Sebagai bantuan yang dapat membantu guru dalam memperbaiki proses belajar mengajar. Apabila para guru menganggap bahwa supervisi sebagai alat kontrol, maka guru tersebut akan enggan bahkan menolak kalau dirinya diselia. Akibatnya ialah problema-problema dalam proses belajar mengajar tidak dapat dipecahkan secara cepat, yang pada gilirannya nanti proses belajar mengajar tidak dapat berjalan secara efektif.

Berdasarkan dari uraian di atas penulis ingin mengadakan penelitian mengenai Efektivitas Pembelajaran Ditinjau dari Pelaksanaan Supervisi.

\section{KAJIAN PUSTAKA}

Secara umum persepsi dapat diartikan sebagai penglihatan, atau bagaimana orang melihat sesuatu. Menurut Hammer dan Organ yang dikutip oleh Indrawijaya (1996) mengatakana bahwa persepsi adalah proses dengan mana sesorang mengorganisasikan dalam pikerannya, menafsirkan, mengalami, mengolah pertanda atau segala sesuatu yang terjadi di lingkungannya. Sedangkan menurut R.J. Corsini (1997) "perception refers both to the experience of gaining sensory information about the world of people, things, and events, and the psychological process by which this is accomplished". Berdasarkan uraian di atas jelaslah bahwa persepsi itu adalah pandangan atau penilaian terhadap sesuatu di lingkungannya baik mengenai orang, sesuatu maupun peristiwa berdasarkan pengalaman dan penginderaan.

Supervisi dapat diartikan sebagai kegiatan membantu guru mengembangkan kemampuannya mengelola proses belajar mengajar. Sehubungan dengan itu Negley yang dikutip Pidarta (1992) berpendapat bahwa supervisi adalah bantuan, pengarahan dan bimbingan kepada guru dalam bidang istruksional, belajar dan kurikulum. Lebih tegas lagi Wiles (1995) mengatakan bahwa supervision is assistance in developing of a better teaching learning situation. Artinya supervisi adalah bantuan dalam mengembangkan situasi belajar mengajar yang lebih baik.

Tujuan supervisi adalah untuk membantu guru dalam mengembangkan situasi belajar mengajar ke arah yang lebih baik. Willes (1995) mengatakan bahwa tujuan supervisi adalah untuk menciptakan siatuasi belajar mengajara yang lebih baik. Bantuan yang diberikan dalam kegiatan supervisi di antaranya adalah; (a) membantu guru memahami dan merumuskan tujuan pengajaran, (b) membantu guru dalam menggunakan sumber atau media pendidikan, (c) membantu guru menilai kemajuan belajar murid, (d) membantu guru membimbing pengalaman belajar murid, (e) membantu guru beradaptasi dengan lingkungan.

Selain hal yang disebutkan di atas, bantuan yang diberikan supervisor kepada guru menurut Subari (1994) juga meliputi sebagai berikut; (a) membantu guru menyeleksi "text-book" (b) Membantu guru membuat persiapan mengajar, (c) membantu guru menggunakan metode mengajar, (d) membantu guru menggunakan AVA, (e) Membantu guru mengatasi problema-problema batin, (f) membantu guru bekerja dalam suasana staf yang harmonis, (g) membantu guru mengenal kebutuhan murid. 
Program supervisi yang baik harus mengikut sertakan guru-guru. Artinya kepala sekolah dan guru-guru secara bersama menyususn program supervisi, baik pada perencanaan, pelaksanaan maupun pada pengevaluasian, sebab guru-gurulah yang paling mengetahui masalah yang dialaminya. Hal ini sejalan dengan apa yang dikatakan Depatemen Pendidikan dan Kebudayaan (1983) dalam buku Suepvisi Klinis bahwa dilibatkannya guru dalam pembuatan perencanaan supervisis dikarenakan supervisi tidak hanya merupakan kebutuhan dan tugas supervisor saja, akan tetapi supervisi merupakan kebutuhan para guru demi perbaikan pengajaran.

Program supervis akan lebih berhasil apabila program tersebut dibarengi dengan berbagai aktivitas yang relevan dengan sasaran serta permasalahan yang dialami oleh guru-guru. Aktivitas-aktivitas supervisi tersebut antara lain dapat dapat berbentuk observasi kelas, konferensi supervisi, diskusi kelompok, pembicaraan individual khusus antara individu dan kepala sekolah, demonstrasi mengajar dan sebahgainya. Intinya adalah bahwa semua usaha yang dilakukan oleh pejabat fungsional sekolah, baik supervisor atau kepala sekolah, untuk memberikan pembinaan kepada guru, dan tenaga kependidikan lainnya yang bertugas dalam dunia pendidikan sehingga dapat membantu dalam meningkatkan mutu pendidikan dan pengajaran.

Paling tidak ada tiga tahapan yang perlu di lalui oleh supervisor dalam memberikan layanan atau bantuan kepada guru-guru. Tahapan tersebut adalah pertemuam sebelum melaksanakan observasi kelas, observasi kelas dan pertemuan setelah observasi kelas.

Pada tahapan pertama yaitu pertemuan sebelum observasi, supervisor dan guru perlu membangun hubungan baik, agar kedua belah pihak tidak merasa kaku dan canggung dalam melak- sanakan kegiatan supervisi. Selain itu agar guru yang membutuhkan bantuan dapat berkomunikasi dengan lancar dalam menyampaikan berbagai permasalahan yang dihadapi guru di lapangan. Apabila terjalin komunikasi yang baik dan lancar antara supervisor dan guru maka akan terbina keakraban dintara mereka. Pada gilirannya nanti guru dapat menyampaikan semua kendala dan hambatan yang dihadapi dalam proses belajar mengajar dengan keakraban, begitu juga semua bimbingan, bantuan dan arahan bahkan kritikan dari supervisor tidak dianggap sebagai mencaricari kesalahan guru. Bila hal ini terwujud maka supervisi tidak lagi dianggap sesuatu yang menakutkan tetapi merupakan sesuatu kebutuhan.

Tahap kedua ialah observasi kelas. Pada tahap ini supervisor mengumpulkan data terhadap hasil interaksi proses belajar mengajar di kelas melalui observasi langsung ke kelas dimana guru mengajar. Data yang dimaksud adalah data kelemahan-kelamahan maupun kebaikan-kebaikan atau keunggulan guru dalam mengajar. Setelah data tentang kelemahan-kelemahan dan hal-hal yang dikuasai dengan baik dalam menyajikan pelajaran di analisis dan kemudian hasilnya disampaikan kepada guru yang bersangkutan.

Tahap ketiga ialah pertemuan setelah observasi kelas. Tujuan pertemuan ini adalah untuk mengevaluasi ketrampilan yang terlihat pada penampilan guru menurut kriteria yang tercantum pada instrumen penilaian yang telah disiapkan dan disetujui bersama antara supervisor dan guru

Ketiga tahapan tersebut di atas dapat diilustrasikan sebagaimana tertera pada gambar. 1 berikut ini; 


\section{Gambar 1. Tahapan Supervisi}

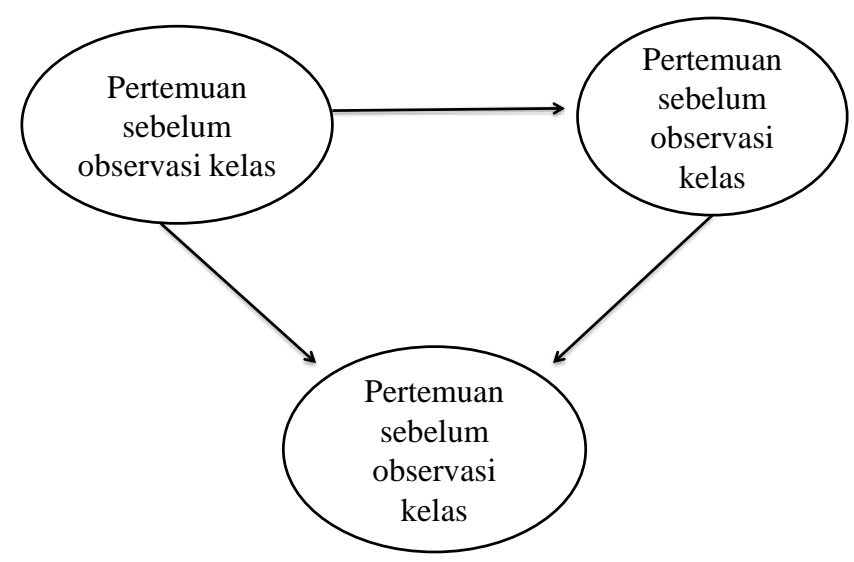

Pendapat Elliot yang dikutip oleh Ansyar (1981) mengatakan bahwa setiap guru mempunyai persepsi, dan perilakunya akan berhubungan dengan persepsi yang dimilikinya. Statemen ini mengindikasikan bahwa bagaimapun seseorang berprilaku pada dasarnya tergantung kepada bagaimana ia memandang peranannya dalam situasi tersebut.

Sebahagian guru yang mempunyai persepsi bahwa supervisi identik dengan evaluasi semata-mata sehingga supervisi tidak disukai bahkan mereka enggan dan menghindarinya. Hal ini terjadi karena supaervisi yang dijalankan didasarkan kepada kebutuhan supervisor semata tanpa memperhatikan bantuan apa sesungguhnya yang dibutuhkan guru dalam meningkatkan kualitas pengajarannya sehingga manfaat supervisi tidak pernah dirasakan guru-guru.

Namun sebaliknya, sebahagian guru mempunyai persepsi yang baik tentang supervisi. Mereka mempunyai persepsi bahwa supervisi merupakan bantuan yang bertujuan menolong guruguru dalam mengatasi persoalan-persoalan dalam menjalankan tugas mengajar mereka. Menurut mereka yang berpersepsi baik terhadap sipervisi. Supervisi sangat dibutuhkan dan bermanfaat. Di negara-negara yang sudah maju guru- guru justru sangat menyukai supervisi, mereka bahkan meminta supaya didatangi oleh supervisor mereka, terutama bila mereka menemukan kendala dalam proses belajar mengajar, terlebihlebih bagi guru-guru muda yang baru bertugas.

Perbedaan persepsi di antara sesama guru terhadap supervisi mungkin disebabkan oleh evolusi supervisi itu sendiri. Sebelum abd XX pelaksanaan supervisi terfocus pada pelaksanaan supervisi sebagai pengawasan atau supervisi sebagai inspeksi. Kemudian pada awal abad ke XX kegiatan supervisi bertujuan untuk peningkatan produktivitas dan efisiensi kerja. Hal ini terjadi mungkin sejalan dengan perkembangan manajemen pada waktu itu yaitu perkembangan praktek manajemen ilmiah. Supervisi pada masa ini terfokus pada penilaian kerja. Tugas supervisor adalah menilai suatu pekerjaan untuk dilaporkan ke atasan.

Di awal abad XXI perkembangan ilmu pengetahuan dan teknologi sangat terasa begitu cepat. Hal tersebut turut mempengaruhi kehidupan social masyarakat pada umumnya dan lembaga pendidikan sekolah pada khususnya. Penerapan teknologi pun dalam dunia pendidikan tak terelakkan lagi. Kondisi se- 
perti ini memaksa guru-guru untuk mampu menguasai dan mengoperasikan teknologi tersebut dalam proses pengajaran. Hal lain yang mungkin menuntut guru-guru untuk senantiasa memacu dirinya menambah pengetahuan dan keterampilan adalah makin mudahnya murid-murid memperoleh sumber pelajaran di luar lingkungan sekolah sehingga tidak tertutup kemungkinan murid-murid sudah menguasai pelajaran sebelum guru menjelaskannya di depan kelas. Bahkan tidak tertutup kemungkinan ada hal-hal yang sudah diketahui oleh murid-murid tetapi justru guru belum menguasainya.

Dengan demikian kompleksnya masalah yang dihadapi oleh guru-guru maka terasa mustahil jika hanya mereka sendiri yang akan berusaha untuk memecahkan masalahnya sendiri. Oleh sebab itulah supervisi mutlak diperlukan untuk membantu memecahkan problema guru dalam hal proses belajar mengajar. Sejak itu pulalah kegiatan supervisi tertuju pada kegiatan layanan atau bantuan kepada guru dalam memecahakan permasalahan-permasalah pengajaran.

Dan sampai sekarang praktekpraktek supervisi sebagai pengawasan, sebagai penilaian atau supervisi sebagai pemberian bantuan masih banyak di terapkan baik supervisor maupun kepala sekolah dalam kapasitasnya sebagai supervisor.

Dari uraian di atas dapat disimpulkan bahwa yang dimaksud dengan persepsi guru tentang supervisi dalam penelitian ini adalah pandangan, peni- laian, pendapat guru mengenai supervisi apakah sebagai pengawasan, penilaian atau bantuan tentang memecahkan permaslahan guru dalam mengoperasikan program belajar mengajar.

Guru adalah pelaksana operasional pendidikan terdepan di sekolah. Guru merupakan faktor yang paling penting terhadap hasil pendidikan. Betapapun canggihnya alat atau teknologi pendidikan, namun dari dahulu sampai sekarang peranan guru sebagai ujung tombak pendidikan belum dapat digantikan oleh benda secanggih apa pun untuk melaksanakan tugas guru tersebut di depan kelas. Oleh sebab itu guru adalah faktor yang sangat menentukan dalam keberhasilan pengajaran.

Keberhasilan pengajaran tidak selalu disertai dengan keefektifan. Keberhasilan pengajaran dikatakan efektif apabila terdapat keampuhan dalam pelaksanaan pengajaran sebagai usaha untuk keseimbangan yang dinamis antara kualitas dan kuantitas pengajaran, disamping keterbatasan sumber dana dan tenaga yang tersedia. Sebaliknya, keberhasilan pengajaran dikatakan tidak efektif apabila pengajaran itu dapat mencapai sasaran, akan tetapi tidak terdapat keseimbangan antara kualitas dan kuantitas pengajaran disamping dana dan tenaga yang tersedia. Hersey dan Blanchard menggambarkan kuantinum keberhasilan yang efektif suatu kepemimpinan dalam hal ini termasuk juga dalam proses belajar mengajar dapat diilustrasikan dalam gambar seperti di bawah ini. 


\section{Gambar 2. Succesful and Effective Teaching}

(Harsey, 1988)

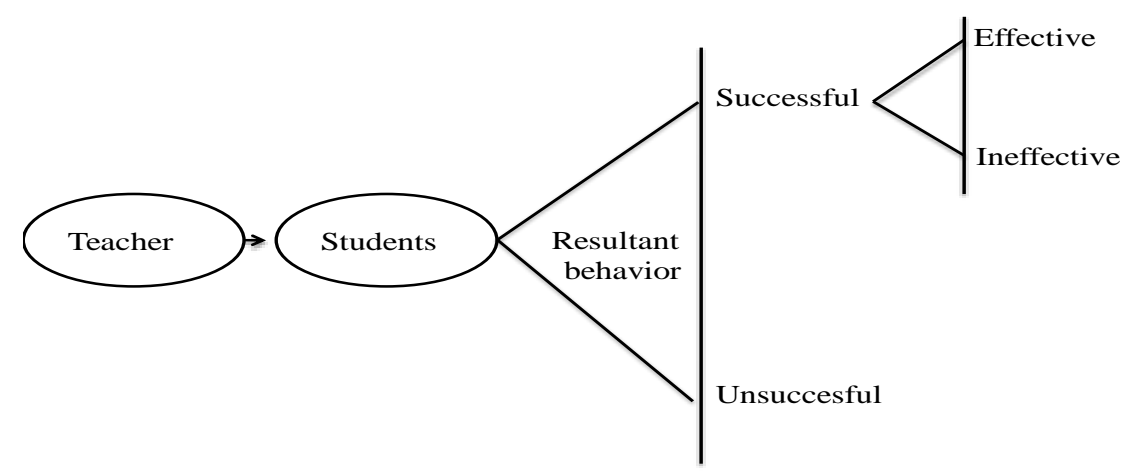

Guru melaksanakan kegiatan belajar mengajar (perilaku) terhadap murid. Proses belajar mengajar tersebut menghasilkan perilaku yang sukses serta perilaku yang tidak sukses, selanjutnya kesuksesan tersebut dapat diklasifikasikan sebagai suatu sukses yang efektif dan sukses yang tidak efektif.

Efektivitas berasal dari bahasa Inggris yaitu effective kata sifat arinya berhasil, ditaati, sedangkan kata bendanya effectiveness yang artinya kefektifan, kemanjuran atau kemujarraban (Echol \& Sadly, 2010). Sedangkan pengajaran dapat diartikan sebagai interaksi antara siswa dengan lingkunan belajar yang diatur oleh guru untuk mencapai tujuan pengajaran (Sujana, 2000). Jadi efektivitas pengajaran dapat diartikan sebagai kemanjuran interaksi antara siswa dengan lingkunagan belajar yang diatur oleh guru untuk mencapai tujuan pengajaran.

Efektivitas pengajaran dapat dilihat dari berbagai aspek. Lucio (1999) mengemukakan criteria untuk menentukan efektivitas pengajaran. Kriteria itu ialah a. proses, b. karakteristik guru, dan c. hasil. Selanjutnya, ketiga criteria itu dijelaskan secara terinci sebagai berikut;
Proses pengajaran menyangkut perilaku guru yang dinilai berdasarkan standar penampilan, misalnya bagaimanakah guru membuat perencanaan, menyajikan serta mengevaluasi pengajaran.

Karakteristik guru berkaitan dengan intelligensi, kesopanan, kefasihan berbahasa, kepribadian, kesehatan dan kejujuran.

Kriteria hasil yakni berupa tingkatan perubahan perilaku murid sesuai dengan tujuan yang ditentukan dalam kegiatan belajar mengajar.

Kriteria efektivitas pengajaran di atas sangat penting untuk diketahui oleh guru agar dapat mengetahui sejauhmana keefektivan mengajarnya dapat diketahuinya. Efektivitas pengajaran dilihat dari segi hasil dapat dibagi menjadi berbagai aspek. Berdasarkan ranah tujuan pengajaran, hasil belajar terdiri dari a. tingkat hasil belajar, dan b. segi isi pelajaran (Merril, 1993). Tingkatan hasil belajar ini mencakup mengingat, mengaplikasikan dan menemukan. Sedangkan segi isi pelajaran, hasil belajar meliputi kaidah, prosedur, konsep dan fakta.

Penelitian ini hanya membahas penilaian efektivitas pengajaran dari segi 
proses. Menurut Departemen Pendidikan dan Kebudayaan (1983) ada tiga komponen kemampuan yang harus dimiliki guru agar proses pengajaran tersebut dikatakan efektif yaitu; (a) kemampuan menrencanakan pengajaran, (b) kemampuan melaksnakan pengajaran dan, (c) kemampuan melaksnakan hubungan antarpribadi. Sedangkan Mouly (1997) megatakan bahwa proses pengajaran yang efektif seorang guru harus mempunyai kemampuan yang digolongkan menjadi tiga kelompok yaitu; (a) mengarahkan dan memotivasi murid, (b) memberikan pengalaman belajar, (c) mengembangkan kepribadian murid secara menyeluruh.

Dari kedua teori di atas dapat disimpulkan efektivitas proses pengajaran mencakup mencakup (a) merencanakan pengajaran, (b) melaksanakan pengajaran, (c) mengevaluasi, (d) memotivasi murid dan (e) melaksanakan hubungan antarpribadi.

Persiapan Pengajaran. Tidak jarang didapati bahwa guru sering sekali mengajar tanpa persiapan mengajar yang baik dan matang sehingga guru kadangkala kelihatan gugup, pembicaraan berputarputar tidak jelas ujung pangkalnya sehingga murid sulit memahami pelajaran dengan baik. Subari (1994) menggolongkan persiapan pengajaran kepada dua macam yaitu persiapan lahir dan persiapan bathin.

Persiapan lahir meliputi persiapan tak tertulis dan persiapan tertulis. Persiapan tak tertulis mencakup mencari sumber pengajaran, mencari alat peraga, mempersiapkanalat pengajaran misalnya kapur, penghapus, over head proyektor, tape recorder dan sebagainya. Sedangkan persiapan tertulis yaitu persiapanpersiapan yang harus dipersiapkan guru dalam bentuk tulisan. Mislanya; satuan pelajaran.

Persiapan bathin adalah persiapan mental antara lain bersikap sabar, berpenampilan tenang, tidak ragu-ragu dan sebagainya.

Melaksanakan pengajaran, perencanaan pengajaran yang dibuat melalui persiapan pengajaran tidak banyak memberikan manfaat apabila tidak dilaksanakan oleh guru di dalam aktivitas pengajaran di depan kelas. Kemampuan melaksanakan pengajaran oleh guru dapat dilihat melalui kemampuan guru menciptakan interaksi belajar antara guru dan siswa atau siswa dengan siswa sesui dengan situasi dan kondisi yang kondusif. Kemampuan melaksanakan pengajaran ini antara lain kemampuan membuka pelajaran, memperkenalkan pelajaran, menngunakan metode pengajaran, dan kemampuan memberi reinforcement (penguatan)

Mengevaluasi, setiap program biasanya diakhiri dengan evaluasi, sebab dengan evaluasi kita tahu sejauhmana suatu tujuan dari suatu program dapat tercapai. Purwanto (1996) berpendapat bahwa evaluasi adalah menilai perkembangan dan kemajuan siawa ke arah tujuan yang telah ditetapkan dalam kurikulum. Sedangkan tujuan dari pada evaluasi adalah untuk memperoleh informasi tentang keberhasilan pengajaran, sikap, minat dan aspek-aspek lain dari siswa.

Salah satu cara untuk menilai pengetahuan, kemampuan, dan keterampilan siswa adalah melalui test. Menurut Dobson (1990) ada beberapa jenis test yang dapat digunakan dalam proses belajar mengajar, antara lain essay test, multiple choice test, completion, True-False dan lain-lain. 
Namun yang paling penting dalam mengevaluasi adalah memilih jenis test yang mana yang paling sesuai dengan materi pelajaran yang akan dilakukan evaluasi.

Memotivasi siswa. Motivasi berasal dari kata movere (Latin) yang artinya menggerakkan. Menurut Huston (1985) motivasi sebagai suatu faktor yang menjadikan perilaku bekerja dengan intuitif, terarah, intensif dan gigih. Berdasarkan definisi di atas bahwa motivasi menunjuk kepada suatu faktor yang menyebabkan sesorang untuk berbuat dalam memenuhi kebutuhannya. Begitu juga halnya siswa belajar, motivasi belajar mereka terkait dengan sejauhmana mereka merasa butuh untuk menguasai pelajaran mereka. Motivasi belajar siswa tidak sama ada yang memiliki motivasi tinggi dan ada pula yang rendah, yang menjadi permasalahan adalah bagaimana meningkatkan motivasi belajar siswa yang rendah menjadi siswa yang memiliki motivasi tinggi. Di sinilah peranan guru sebagai mitivator. Mereka selalu dituntut untuk memotivasi, mengarahkan dan membimbing siswa agar mau dan aktif belajar.

Melaksanakan hubungan antar pribadi. Hubungan antarpribadi seseorang dengan orang lain merupakan bagian penting dari kehidupan manusia seharihari. Hubungan antarpribadi tidak bersifat statis, artinya hubungan antarpribadi dapat berubah. Adakalanya hubungan antarpribadi antara seseorang dengan orang lain sangat harmonis dan ada kalanya bisa renggang. Dalam interaksi belajar mengajar pun bisa terjadi hubungan antarpribadi yang harmonis atau konflik. Adalah kewajiban guru untuk terus membina hubungan antarpribadi yang harmonis dan mencegah knflik dalam belajar baik antara guru dengan siswa maupun antara siswa dengan siswa yang lain.

Hubungan antarpribadi dengan siswa meliputi kemampuan berhubungan sebagai berikut

1. Kemampuan untuk membantu mengembangkan sikap positip pada diri siswa. Kemapuan ini terdiri dari halhal sebagai berikut;

a. Kemampuan membantu siswa menyadari kekuatan dan kelemahan dirinya

b. Kemampuan membantu siswa menumbuhkan kepercayaan pada diri sendiri

c. Kemampuan membantu siswa menjelaskan pikiran dan perasaan siswa

d. Kemampuan membantu siswa agar mampu mengambil keputusan yang sesuai bagi dirinya.

2. Kemampuan bersikap terbuka dan luwes terhadap siswa atau orang lain.

Kemampuan ini terdiri atas;

a. Kemampuan menunjukkan sikap terbuka terhadap pendapat siswa dan orang lain.

b. Kemampuan menunjukkan sikap luwes baik di dalam maupun di luar kelas.

c. Kemampuan menerima siswa sebagaimana adanya (kelebihan dan kekurangan)

d. Kemampuan menunjukkan sikap simpatik dan sensitif terhadap perasaan dan kesukaran siswa.

e. Kemampuan menunjukkan sikap ramah, penuh pengertian, dan sabar baik kepada siswa maupun orang lain.

3. Kemampuan menampilkan kegairahan dan kesungguhan dalam kegiatan belajar mengajar dan pelajaran yang 
diajarkannya. Kemampuan ini meliputi;

a. Kemampuan menunjukkan kegairahan dalam mengajar.

a. Kemapuan merancang minat siswa untuk belajar.

b. Kemampuan memberikan apa yang diajarkan dan cara mengajarkannya.

4. Kemampuan mengembangkan hubungan antarpribadi yang sehat dan serasi. Kemampuan ini terdiri atas:

a. Kemampuan mengadakan hubungan antarpribadi yang sehat dan serasi.

b. Kemampuan memberikan tuntutan agar interaksi antar siswa serta antar guru dan siswa terpelihara dengan baik.

c. Kemampuan menangani perilaku siswa yang tidak iinginkan (Imron, 1995).

Berdasarkan uraian di atas maka yang dimaksud dengan efektivitas pengajaran dalam penelitian ini adalah kemanjuran atau ketepatan interaksi antara siswa dengan guru untuk mencapai tujuan pengajaran.

Adapun untuk mengukur efektivitas pengajarn guru semua bidang studi baik pelajaran Qur'an hadis, Aqidah akhlak, Fiqh, Sejarah Kebudayaan Islam, PPKN Bahasa Indonesia, Bahasa Arab, Bahasa Inggris, Sejarah, Pendidikan Jasmani dan Kesehatan, maupun Fisika, Biologi, Kimia dan Matematika adalah kelima komponen kemampuan mengajar yang telah disebutkan di atas.

\section{METODE PENELITIAN}

Penelitian ini menggunakan metode deskriptif exploratif. Nazir (2000) mengatakan metode deskriptif ialah suatu metode dalam meneliti suatu objek atau peristiwa pada masa sekarang. Penelitian ini juga menggunakan statistik yakni alat yang dapat membantu dalam menarik kesimpulan umum yang dapat diandalkan, karena penelitian ini melakukan pengujian hipotesis tentang hubungan antara dua variable maka analisis yang dipakai adalah analisis korelasi.

Variable yang dikaji dalam penelitian ini dibedakan atas dua variable yaitu variable bebas dan variable terikat. Variabel bebas adalah persepsi tentang supervisi sedangkan variable terikat adalah efektivitas pengajaran.

Populasi dapat diartikan sebagai keseluruhan subject penelitian. Maka dari itu yang menjadi populasi penelitian ini adalah seluruh guru Madrasah Aliyah Negeri 1 Padangsidimpuan. berjumlah 45 orang, yang terdiri dari guru pegawai negeri sipil (PNS) dan honorer.

Sampel adalah sebahagian atau wakil dari populasi yang diteliti. Riyanto (1996) mengatakan smpel adalah "himpunan yang merupakan bagian dari suatu populasi" Dari definisi di atas dapat disimpulkan bahwa sample adalah sautu himpunan, atau kelompok yang merupakan wakil atau bagian dari populasi.

Seperti telah di sebutkan di atas bahwa populasi atau jumlah guru Madrasah Aliyah Negeri 1 PadangSidimpuan, dan sesuai dengan kriteria yang menjadi populasi penelitian ini yaitu gur PNS maka yang berhak menjadi populasi sebanyak 40 orang. Jadi penelitian ini tidak mengadakan penarikan sampel.

Adapun alat pengumpulan data yang digunakan dalam penelitian ini 
adalah angket atau kuesioner. Kuesioner tersebut disusun menurut skala Likert. Penulis menggunakan skala ini karena model ini dianggap sangat sesuai untuk menanyakan pendapat atau sikap seseorang terhadap suatu objek. Hal ini sesuai dengan pendapat Bruce $\mathrm{W}$ Tuckman sebagai berikut "This scale is used to register the extend of agreement or disagreement with a particular statement of an attitude, belief, or judgement".

Skala Likert adalah suatu model skala dalam bentuk kontinum yang jawabannya terdiri dari lima skala yaitu; (a) Sangat Setuju (SS), (b) Setuju (Setuju), (c) Agak Setuju (AS), (c) Tidak Setuju (TS) dan (d) Sangat Tidak Setuju (STS). Sesuai dengan sifat kuesioner maka pernyataan dibedakan menjadi dua kelompok yaitu favorable dan unfavorable. Item yang bersifat favorable ialah pernyataan yang bersifat. Jawaban (SS) diberikan nilai 5, (S) nilai 4, (AS) nilai 3, (TS) nilai 2, dan (STS) nilai 1. Sedangkan item unfavorable yaitu pernyataan yang bersifat negative. Jawaban (SS) diberi nilai 1, (S) nilai 2, (AS) nilai 3, (TS) nilai 4 dan (TST) nilai 5 .

Penalitian ini diolah dan dianalisis dengan menggunakan korelasi. Namun sebelum melakukan analisis data, terlebih dahulu dilakukan pengujian persyaratan analisis yaitu melakukan uji normalitas. Tujuan uji normalitas untuk mengetahui apakah data respondent berdistribusi normal atau tidak, barulah dilakukan analaisis atau pengujian hipotesis.

Teknik analisis yang digunakan dalam pengujian hipotesis ini adalah teknik analisa korelasi. Teknik analisis korelasi dilakukan untuk mengetahui hubungan antara variable persepsi guru tentang supervise $(\mathrm{X})$ dengan variable efektifitas pengajaran (Y).

Rumus korelasi yang digunakan untuk menguji korelasi antara kedua variable adalah rumus Product moment correlation oleh Pearson. Untuk memudahkan analisisnya penulis menggunakan alat bantu komputer. Adapun program yang digunakan adalah program SPSS. Selanjutnya, untuk melihat koefisien korelasi antara variable bebas persepsi tentang supervise atau variable (X) dengan variable terikat efektivitas mengajar atau (Y) dilakukan dengan menggunakan uji t.

\section{HASIL PENELITIAN}

Setelah data terkumpul maka skor yang diperoleh dari jawaban responden untuk variabel persepsi tentang supervisi menyebar mulai dari skor 113 sampai dengan 147. Dari pengolahan data tersebut diperoleh skor rata-rata 126.07, median 125.96, modus 127.14, dan simpangan baku sebesar 7.48. Hal ini menunjukkan salah satu indikasi bahwa skor variabel persepsi tentang supervisi cenderung membentuk distribusi normal.

Hasil pengelompokan skor jawaban responden memperlihatkan bahwa pengelompokan data untuk variabel persepsi tentang supervisi adalah $15 \%$ dalam kategori tinggi, $67,5 \%$ berada dalam kategori sedang dan $17,5 \%$ dalam kategori rendah.

Skor yang diperoleh dari jawaban responden untuk variabel efektivitas pengajaran menyebar mulai dari skor 108 sampai dengan 139. Dari pengolahan data tersebut diperoleh skor ratarata 124.22 , median 123.88 , modus 124.50, dan simpangan baku sebesar 9.36. Hal ini menunjukkan salah satu indikasi bahwa skor variabel persepsi 
tentang supervisi cenderung membentuk distribusi normal.

Hasil pengelompokan skor jawaban responden memperlihatkan bahwa pengelompokan data untuk variabel persepsi tentang supervisi adalah $15 \%$ dalam kategori tinggi, $70 \%$ berada dalam kategori sedang dan $15 \%$ dalam kategori rendah.

Seperti telah disebutkan pada bab terdahulu bahwa hipotesis penelitian ini adalah "Terdapat hubungan antara persepsi tentang supervisi dengan efektivitas pengajaran".
Perhitungan korelasi antara variabel persepsi tentang supervisi dan efektivitas pengajaran yang dilakukan diperoleh $r_{x y}=0.43$. Uji keberartiannya menggunakan statistik distribusi t. Harga t dari perhitungan adalah 2,95 Sedangkan harga $t_{t}(38)(0,05)$ adalah 2,04. Sedangkan harga yang diperoleh tersebut $\mathrm{t}_{\mathrm{h}} \odot \mathrm{t}_{\mathrm{t}}$. Sehingga pada signifikan 0,05 , koefisien korelasi 0,432 dinyatakan signifikan.

Rangkuman analisis korelasi dan koefisien korelasi tersebut dapat dilihat pada table seperti di bawah ini;

Tabel Rangkuman Hasil Analisis Korelasi Dan Uji "T"

\begin{tabular}{ccccc}
\hline Korelasi & $\begin{array}{c}\text { Koefisien } \\
\text { Korelasi }\end{array}$ & $\begin{array}{c}\text { Koefisien } \\
\text { Determinasi }\end{array}$ & \multicolumn{2}{c}{ Signifikansi } \\
\cline { 4 - 5 } \cline { 4 - 5 }$(\mathrm{r})$ & $\left(\mathrm{R}^{2}\right)$ & T hit. & T tab. \\
\hline $\mathrm{r}_{\mathrm{xy}}$ & 0.43 & 0,18 & 2,95 & 2,04 \\
\hline
\end{tabular}

Tabel di atas menunjukkan bahwa $\mathrm{t}$ hitung lebih besar dari $\mathrm{t}$ table. Ini berarti terdapat hubungan yang signifikan antara variabel persepsi tentang pelaksanaan supervise dengan efektivitas pengajaran. Kemudian pada taraf $\alpha=0,5$ koefisien korelasi sebesar 0,43 menunjukkan bahwa variasi yang terjadi pada variabel efektivitas pengajaran sebesar 0,18 dapat ditentukan oleh variabel persepsi tentang pelaksanaan supervise. Hal ini berarti hypothesis yang diajukan dalam penelitian ini dapat diterima.

Hasil penelitian ini menunjukkan bahwa terdapat hubungan yang significan antara persepsi guru tentang pelaksanaan supervise dengan efektivitas pengajaran.

Hasil pengujian hipotesis menunjukkan bahwa persepsi pelaksanaan supervise mempunyai hubungan positif dengan efektivitas pengajaran yaitu sebesar 0, 43. Kekuatan hubungan memiliki koefisien determinasi sebesar 0 , 18. Hal ini menunjukkan bahwa variasi yang terjadi pada variabel efektivitas pengajaran guru sebesar $18 \%$ ditentukan oleh persepsi guru tentang pelaksanaan supervise.

Temuan penelitian ini memperlihatkan bahwa persepsi tentang pelaksanaan supervise dan efektivitas pengajaran mempunyai hubungan yang signifikan.

Penelitian ini mendukung penelitian yang dilakukan Rbinson yang mengatakan bahwa $30 \%$ guru yang diteliti memerlukan bantuan supervise dalam pelaksanaan pengajaran. Hasil penelitian ini disamping mendukung penelitian yang dilakukan oleh Robinson di atas juga mendukung pendapat Keutch A Acheson dan Meredith Damien Gall yang mengatakan bahwa banyak penelitian menunjukkan bahwa 
bantuan mengajar efektif dalam meningkatkan ketrampilan mengajar.

\section{KESIMPULAN DAN SARAN}

Kesimpulan penelitian ini adalah sebagai berikut;

1. Persepsi guru tentang pelaksanaan supervise guru-guru Madrasah Aliyah Negeri 1 Padangsidimpuan dapat dikatakan sedang sja. Hal ini dapat diketahui dari persentase penyebaran skor variabel konsep diri ini yaitu $15 \%$ dalam kategori tinggi, 67,5\% dalam kategori sedang dan 17,5\% dalam kategori rendah.

2. Efektivitas pengajaran dapat juga dikatakan sedang sja. Hal ini dapat diketahui dari persentase penyebaran skor variabel efektivitas pengajaran menunjukkan $15 \%$ dalam kategori tinggi, $70 \%$ dalam kategori sedang dan $15 \%$ dalam kategori rendah.

3. Hasil penelitian ini memperlihatkan bahwa ada hubungan persepsi guru tentang pelaksanaan supervise dengan efektivitas pengajaran. Hal ini berarti bahwa persepsi tentang pelaksanaan supervise merupakan salah satu faktor yang dapat mempengaruhi efektivitas pembelajaran di kelas.

Berdasarkan hasil penelitian yang telah dipaparkan di atas dikemukakan saran-saran sebagai berikut;

1. Guru dalam meneningkatkan efektivitas cara mengajarnya hendaknya berdasarkan kemauan, motivasi dan prakarsa sendiri, bukan karena takut kepada supervisor. Di samping itu para guru hendaknya merubah persepsi negatif terhadap supervisor agar tercipta hubungan yang harmonis antara guru dengan supervisor pada saat pelaksanaan supervisi dilakukan. Guru hendaknya bersifat terbuka terhadap saran-saran yang diberikan supervisor

2. Supervisor hendaknya lebih memfokuskan pelaksanaan supervisi terhadap hala-hal yang berhubungan secara langsung dengan pembinaan, peningkatan ketramilan dan prilaku guru dalam mengelola proses belajar mengajar. Supervisor dalam menjalankan supervisi diharapkan lebih doinan memposisikan dirinya sebagai kolega dari pada sebai administrator.

3. Kepala Kantor Kementerian Agama RI Kota Padangsidimpuan juga harus terus membina para supervisor yang ada di wilayah kota Padangsidimpuan, baik melalui persyaratan menjadi supervisor, frekwensi kunjungan ke sekolah, maupun kompetensi yang sesuai dengan bidangnya.

4. Peneliti Lanjutan. Efektivitas pengajaran dapat dikaji dari berbagai faktor. Penelitian ini hanya membahas dari faktor pelaksanaan supervisi saja sedangkan faktor-faktor efektivitas pengajaran yang lain masih banyak. Sehubungan dengan itu disarankan kepada para membaca agar dapat mengadakan penelitian lanjutan mengenai efektivitas pengajaran lebih mendalam lagi. 


\section{DAFTAR RUJUKAN}

Acheson, Keith A and Gall, Meredith Damien, 1887.Techniques in The Clinical Supervision of Teachers, London: Longman.

Arikunto, Suharsimi, Prosedur Penelitian, Suatu Pendekatan Praktik, Jakarta: Rineka Cipta, 1991.

Ansyar, Mohammad. 1981. A Study of Teacher and Students Perceptions of Exixting and Recommended Curriculum Goal and Practice in West Sumatra, Indiana: Indiana University.

Corsin, R.J. 1987. Concise Encyclopedia of Psychology, New York: John Wiley and Son.

Departemen Pendidikan dan Kebudayaan. 1983. Supervisi Klinis, Jakarta: Ditjen Pendidikan Tinggi.

Departemen Pendidikan dan Kebudayaan. 1982. Dasar-dasar Ilmu Pendidikan, Jakarta: Ditjen Pendidikan Tinggi.

Departemen Pendidikan dan Kebudayaan. 1983. Alat Penilaian Kemampuan Guru, Jakarta: Ditjen Perguruan Tinggi.

Dobson, Julia, 1990. A TEAFL Anthology, Selected Articles from The English Forum, Washington: International Agency.

Echol, John $\mathrm{M}$ and Shadly, Hassan, 2010. Kamus Inggris Indonesia, Jakarta: Gramedia.

Hasby, Abdullah, Teknik Evalusi, Banda Aceh: Fakultas Tarbiyah IAIN Arraniry, 1985.

Hersey, Paul and Blanchard, Kenneth $\mathrm{H}$. 1988. Management of Organizational Behavior, Utilizing
Human Resources, New Jersey: Prentice Hall.

Huston, John P. 1985. Motivation, New York: Mc Millan Publishing Company.

Imron, Ali, 1995. Pembinaan Guru di Indonesia, Jakarta: Pustaka Jaya.

Indrawijaya, Adam I. 1986. Perilaku Organisasi, Bandung: Sinar Baru.

Intan, Nur, Persepsi Siswa SMA Negeri 2 Plus Mata Uli Sibolga terhadap Efektivitas Proses Belajar Mengajar.

(Skripsi), Padangsidimpuan: STAIN Padangsidimpuan, 2002.

Licio, William H and Mc Neil, John D. Mc. 1999. Supervision in Though and Action, New York: Mc Graw Hill Company.

Merril, David M, Compnent. 1993. Display Theory, Los Angeles: University of Southern California.

Nazir, Moh. 2000. Metode Penelitian, Jakarta: Ghalia.

Riyanto, Yatim, 1996. Metodologi Penelitian Pendidikan, Suatu Tinjauan Dasar, Surabaya: SIC.

Pidarta, Made. 1992. Pemikiran Tentang supervisi Pendidikan, Jakarta: Bumi Aksara.

Purwanto, Ngalim. 1996. Prinsip-prinsip dan Teknik Evaluasi Pengajaran, Bandung: Remaja Karya.

Robinson, John J. 1978. ERIC Clearing house on Education, (The Observation Report - A Help or Nuisance), November.

Subari, 1994. Supervisi Pendidikan, Dalam Rangka Perbaikan Situasi Mengajar, Jakarta: Bumi Aksara. 
14 Ta'dib, Volume 19, No. 1 (Juni 2016)

Sujana, Nana. 2000. Dasar-dasar Proses Belajar Mengajar, Bandung: Sinar Baru Algensindo.

Tuckman, Bruce W. 1978. Conducting Educational Research, Toronto:

Harcourt Bruce Jovanovic Publishers.

Wiles, Kimbal, 1955. Supervision for Better School, New York: Prentice Hall. 